\title{
Precedent at the Court of Justice of the European Union: The
}

\section{Linguistic Aspect}

\section{Karen McAuliffe}

\section{Introduction}

The development of a de facto precedent in EU law has recently been the subject of significant academic debate. There is no official doctrine of precedent in EU lawhistorically, a doctrine of binding precedent would have been entirely inappropriate in what was originally

a court of first and last resort, many of whose decisions could only be changed by amending the Treaties ... it was imperative that the Court should have the power to ... depart from its previous decisions. ${ }^{1}$

\footnotetext{
* Senior Lecturer, School of Law, University of Exeter. This paper is based on the results of periods of participant observation at the ECJ of the European Communities undertaken between 2002 and 2006; all comments/criticisms are welcome (k.mcauliffe@exeter.ac.uk). Unless otherwise indicated all quotes are taken from interviews with référendaires, judges, advocates general, and lawyer-linguists at that Court.

I would like to thank Dr Robert Harmsen of the University of Luxembourg for his support and valuable comments. I would also like to thank my former colleagues at the ECJ in Luxembourg for their assistance with this research — in particular Mr Alfredo Calot-Escobar and Ms Susan Wright.

Any errors are mine alone.
}

${ }^{1}$ A Arnull, 'Owning Up to Fallibility: Precedent and the Court of Justice' (1993) 30 CMLR $247,248$. 
In spite of this, however, the Court of Justice of the European Union (ECJ) does on occasion appear to regard its previous decisions as establishing law that should be applied in later disputes. For example, as noted by Komarek, the ECJ's line of cases beginning with Brasserie du Pêcheur/Factortame III ${ }^{2}$ (establishing liability of the state for breach of EU obligations) changes the distinction between 'binding force' and 'legal effects' of the ECJ's judgments as drawn by Toth in $1984^{3}$ : following this line of case law it appears that the ECJ has introduced a system of precedent and 'tied down' national courts without establishing a formal hierarchy in the strict sense. ${ }^{4}$ Thus, in spite of the fact that the doctrine of stare decisis was not formally recognised by the civil law tradition of the EU's founding states, nor by international law, the ECJ 'worked assiduously to develop what is now a robust and takenfor-granted set of practices associated with precedent' ${ }^{5}$ While those practices may well be 'taken-for-granted' this is not to say that they are clear or uncomplicated. As Komarek points out, the EU brings together many different legal orders from civil and common law traditions and the result, in terms of the status of the ECJ's decisions in EU law is somewhat puzzling. ${ }^{6}$

\footnotetext{
${ }^{2}$ Joined Cases C-46/93 and C-48/93.
}

${ }^{3}$ A Toth, 'The authority of judgments of the European Court of Justice: Binding force and legal effects' (1984) 4 Yearbook of European Law 1.

${ }^{4}$ J Komarek, 'Federal Elements in the Community Judicial System: Building Coherence in the Community Legal Order' (2005) 42 CMLR 9, 16. See, in particular, the Köbler and Larsy decisions.

${ }^{5}$ Alec Stone Sweet, The Judicial Construction of Europe (Oxford University Press, Oxford, 2004), 97-8

${ }^{6}$ J Komarek, 'Judicial lawmaking and precedent in supreme courts: The European Court of Justice compared to the US Supreme Court and the French Cour de cassation' (2008-09) 11 CYELS 399. 
On the one hand, according to the Treaty on the Functioning of the European Union (TFEU) Art.228, the decisions of the ECJ are binding only on those to whom they are addressed. On the other hand, however, in order to know how to apply the substantive law of the EU, we must consult decisions of the ECJ. Furthermore, it is in fact through those decisions that the EU legal order has developed: it is generally accepted that most of the 'constitutional law' of the EU has been developed, not in the treaties, but through the case law of the ECJ. ${ }^{7}$ As Komarek states, this 'puzzle' of EU law is well illustrated by the major treatise on the EU judicial system which states that the 'case law — those in theory not formally binding - is often the most important source of law, ${ }^{8}$ Certainly, 'judicial supremacy has been a central seam in the EU legal order'. 9

There are, of course, many different interpretations of the notion of precedent. The question of whether precedent refers to normative implications that a judgment may have beyond the context of a particular case or to the strict formal binding force of a judgment is a perennial one. In EU law, the development of 'precedent' is inextricably linked to the procedure for references for a preliminary ruling under TFEU Art.267. It is often said that national courts are 'European courts', but equally the ECJ is 'not merely a supranational court' but in the fields of 'civil, criminal and administrative law ... has become part of

\footnotetext{
${ }^{7}$ In particular the doctrines of Supremacy and Direct Effect. cf. Case 26/62 Van Gend en Loos v Nederlandse Administratie der Belastingen [1963] ECR 1; Case 6/64 Costa v ENEL
} [1964] ECR 585. Over the years the parameters of those two doctrines have gradually been broadened.

\footnotetext{
${ }^{8}$ Komarek, 'Judicial lawmaking and precedent in supreme courts' (cited in n.6).

${ }^{9}$ Komarek, 'Judicial lawmaking and precedent in supreme courts' (cited in n.6).
} 
national judicial structures'. ${ }^{10}$ And it fulfils all of its roles in this regard through the preliminary ruling procedure. The ECJ has based much of its reasoning in relation to both the development of the principle that its decisions have binding force on all national courts as well as other authorities ${ }^{11}$ and justifying its jurisdiction and decisions under TFEU Art.267 on the need to ensure the 'uniform application of EU law'. The question raised by commentators researching 'precedent' in EU law is thus: what exactly is meant by uniformity? It is generally agreed that 'absolute sameness' is unachievable in any legal system ${ }^{12}$; and Chalmers notes that more 'precedents' do not necessarily mean more uniformity. ${ }^{13}$ According to Dyrberg, however, 'uniform application is ... a sort of existential problem to which the [Union] legal order has to relate ${ }^{14}$-i.e. that a presumption of uniformity is necessary for the ECJ to claim authoritative status within the EU legal order-which, as pointed out by Komarek, aims at supremacy of EU law rather than uniformity itself. ${ }^{15}$

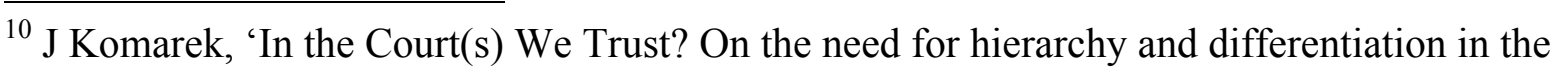
preliminary ruling procedure' (2007) European Law Review 467, 484.

${ }^{11}$ See, in particular the Köbler decision, which attaches the sanction of liability in the case of non-compliance with the Court's previous case law.

${ }^{12}$ M Dougan, National Remedies Before the Court of Justice. Issues of Harmonisation and Differentiation (Hart, Oxford, 2004); Komarek, 'In the Court(s) We Trust?' (cited in n.10).

${ }^{13}$ D Chalmers, 'The dynamics of judicial authority and the Constitutional Treaty' in Altneuland: The EU Constitution in a Contextual Perspective, JHH Weiler and CL Eisgruber (eds) (Jean Monnet Working Paper 5/04, 2004).

${ }^{14}$ P Dyrberg, 'What Should the Court of Justice be Doing?' (2001) 26 European Law Review 291.

${ }^{15}$ Komarek, 'In the Court(s) We Trust?' (cited in n.10). 
It is clear that these questions surrounding the concept of precedent itself and the meaning or understanding of that concept in the EU legal order will continue to interest scholars for some time to come. There is, however, one important aspect of the development of a de facto precedent in ECJ judgments which has been thus far overlooked in the literature: the linguistic aspect. The present paper seeks to address that gap in the literature by analysing the process behind the drafting of judgments at that court.

\section{Drafting judgments at the ECJ}

There are 23 potential languages of procedure for actions before the ECJ. ${ }^{16}$ For practical purposes, that court operates using a single internal working language-French. ${ }^{17}$ The Rules of Procedure provide that judges or advocates general may request the translation of any document into the language of their choice. ${ }^{18}$ However, the members have been obliged to forgo that choice in order not to increase the workload of the translation service and, the judges must work solely in French. However, because French is rarely the mother tongue of

${ }^{16}$ The 23 'official languages' of the EU. These are, in English alphabetical order: Bulgarian; Czech; Danish; Dutch; English; Estonian; Finnish; French; German; Greek; Hungarian; Irish; Italian; Latvian; Lithuanian; Maltese; Polish; Portuguese; Romanian; Slovakian; Slovenian; Spanish: and Swedish. The official order of these languages is to list them according to the way they are spelled each in their own language.

${ }^{17}$ The Rules of Procedure of the ECJ state (in Art.29(5)) that 'The President of the Court and the Presidents of Chambers in conducting oral proceedings, the Judge Rapporteur both in his preliminary report and in his report for the hearing, Judges and Advocates General in putting questions and Advocates General in delivering their opinions may use one of the [official languages] other than the language of the case'. In practice, however, the language used is French.

${ }^{18}$ Rules of Procedure of the ECJ Art.30. 
those drafting that case law, the texts produced are often stilted and awkward. In addition, those drafting such case law are constrained in their use of language and style of writing (owing to pressures of technology and in order to reinforce the rule of law). These factors have led to the development of a 'Court French' which necessarily shapes the case law produced and has implications for its development, particularly insofar as it inevitably leads to a type of linguistic precedent in that case law.

\section{Référendaires}

Each judge and advocate general of the Court of Justice and each judge of the General Court has a cabinet $^{19}$ — a small team of personal legal assistants and secretaries working exclusively for him or her. Those personal legal assistants are known as référendaires,${ }^{20}$ and work very closely with 'their' judge or advocate general, carrying out preliminary research on a case, drawing up procedural documents and preparing 'first drafts' of judgments, etc. The role of the référendaire at the Court of Justice of the European Union has been compared with that of the Conseiller-référendaire of the French Cour de Cassation (a judge attached to that court to assist its senior members) ${ }^{21}$ and with the law clerk of the American judicial system. ${ }^{22}$

${ }^{19}$ While 'cabinet' may be translated into English as 'chambers' the French term is used throughout this paper for two reasons: first, to avoid confusion with the use of the word 'Chamber' for a subdivision of the Court; secondly, unlike the English word 'chambers', 'cabinet' in the context of the Court is used to refer both to the judge's or advocate general's suite of rooms and to the staff working there.

${ }^{20}$ Again, the French word référendaire is used throughout this paper instead of the English translation 'legal secretary', since it is by that title that those assistants are known within the Court, the working language being French.

${ }^{21} \mathrm{~N}$ Brown and T Kennedy, The Court of Justice of the European Communities (Sweet \& Maxwell, London, 2000). 
There are currently 62 cabinets at the Court of Justice of the European Union (excluding the Civil Service Tribunal): there are 27 judges' cabinets from both the Court of Justice and the General Court plus eight advocates general's cabinets.

As already mentioned, référendaires work exclusively for the judge or advocate general to whose cabinet they are attached. They are recruited by the Member him- or herself and, that being so, they are not permanent staff of the Court of Justice of the European Union. The minimum requirement to be a référendaire at the Court of Justice is to be a qualified lawyer with a good knowledge of EU law and with at least a reasonable knowledge of French. ${ }^{23}$ Almost without exception référendaires come from backgrounds of 'practising' lawyers - be they members of the bar of their own Member States, lawyers in large European law firms or, as is the case for many from civil law jurisdictions, law clerks for Member State courts or government agencies/organisations. When new judges or advocates general come to the Court they generally bring their own staff with them, although they sometimes keep the staff of the cabinet of the departing Member and they do frequently try to recruit as least one référendaire from the institution itself as:

it is useful to have at least one member of the cabinet who knows and understands how the institution works [judge].

${ }^{22}$ SJ Kenney, 'Beyond Principals and Agents: Seeing courts as organizations by comparing Référendaires at the European Court of Justice and Law Clerks at the U.S. Supreme Court' (2000) 33 Comparative Political Studies 593.

${ }^{23}$ In spite of the fact that référendaires are required to work wholly in French they are not required to have a 'perfect' command of that language. If a référendaire is not sufficiently competent in the French language, however, it can cause problems for the judge in whose cabinet he or she works - as discussed later in this paper. 
Increasingly, however, lawyer-linguists from the ECJ's Translation Directorate are being seconded to cabinets to work as référendaires. Of the 13 référendaires interviewed for the purposes of the present paper, two had previously worked as lawyer-linguists at the Court (and are officially classed as lawyer-linguists on 'indefinite secondment'); seven had worked as 'practising lawyers' (at the bar or for law firms); three as law clerks; and one as a legal academic before coming to the Court. It is common for the référendaires to be of the same nationality as the judge or advocate general to whose cabinet they are attached; however this is by no means invariably the case - in fact, many judges attempt to have at least one francophone référendaire in their cabinet (since the internal working language of the Court is French and all judges' référendaires must work entirely in French).

The role of a référendaire differs to a considerable degree depending on whether he/she works for a judge, the President of the Court, or an advocate general. The present paper is concerned only with judge's référendaires, whose role is principally to assist the judge in drafting documents such as reports for the hearing, judgments, and, in the case of the presidents of the Court of Justice and the General Court, orders.

\section{Judges' référendaires and the drafting process}

In a judge's cabinet, référendaires work on cases for which 'their' judge is the judge rapporteur and on other cases that are being heard by the chamber in which their judge sits but for which he or she is not rapporteur. ${ }^{24}$ Because of the extremely high workload at the

\footnotetext{
${ }^{24}$ For every action before the Court a 'judge rapporteur' is appointed by the President of the Court. The judge rapporteur is responsible for monitoring the progress of the case, drafting the reports at various stages of the procedure as well as the draft judgment.
} 
Court, it is not possible to allocate work to référendaires on the basis of expertise. ${ }^{25}$ All of the référendaires interviewed for the purposes of the present paper claimed that they had to be 'generalists' who are 'knowledgeable about every area of EU law'. Not only that, they also have to be able to understand and use their knowledge in French-a language that may not be (and indeed in most cases is not) their mother tongue.

Once a case has been assigned to the judge rapporteur, the référendaire dealing with that case will open a file and wait for the submissions to be lodged at the registry of the Court and, where necessary, be translated into French. Not until all of the documents have been translated can the référendaire begin to prepare the preliminary report (rapport préalable) and, where relevant, the report for the hearing. ${ }^{26}$ The report for the hearing is basically a summary of the facts alleged and arguments of the parties and interveners (if any). It is drafted in French and a version of that report in the language of the case is sent to the parties and, at the hearing, it is made public, also in the language of the case. ${ }^{27}$ Because it is a public document which is sent to the parties (who may object) the référendaire's hands are tied as regards framing the facts or arguments in a particular way - the report for the hearing is

${ }^{25}$ cf. K McAuliffe, 'Hybrid Texts and Uniform Law? The Multilingual Case Law of the Court of Justice of the European Union' (2011) 24(1) International Journal for the Semiotics of Law.

${ }^{26}$ In reality many cabinets begin drafting the preliminary report, the report for the hearing, and sometimes even the judgment (as reported by a référendaire from one particular cabinet) as soon as all of the parties' submissions have been lodged, i.e. without waiting for translation of those documents.

${ }^{27}$ Note: until 2004 where there was no hearing in a case the report produced was known as the report of the judge rapporteur. However, the practice of producing such a report in cases that do not require an oral hearing was abolished in 2004. 
therefore often largely 'cut-and-paste' from the relevant submissions. ${ }^{28}$ The preliminary report, which is also written in French, is usually drafted in parallel with the report for the hearing. Those two documents are largely the same in their summary of the facts, law, and relevant arguments. However, the preliminary report is an internal document and it contains a section known as the 'Observations of the Judge-Rapporteur', which comprises the judge rapporteur's opinion on the case and his or her recommendations as to how the Court should rule.

Following the delivery of the advocate general's opinion, the judge rapporteur may begin to draft the judgment. ${ }^{29}$ In reality it is the référendaire assigned to the case who drafts,

${ }^{28}$ Note: this practice is considered 'dangerous' by the vast majority of lawyer-linguists at the Court since the documents from which the référendaires usually 'cut-and-paste' are in fact translations of the original submissions - aside from the accepted 'approximation' in the translation process, those translations are often rushed and frequently contain discrepancies or even errors. For this reason, many lawyer-linguists actually go back to the original submissions when translating the report for the hearing 'back' into the language of the case (cf. Karen McAuliffe, 'Law in Translation: The Production of a Multilingual Jurisprudence by the Court of Justice of the European Communities', PhD Thesis, The Queen's University of Belfast, 2006). The real danger, however, arises at the stage of translation of the judgment - if the lawyer-linguist in question does not understand the language of the case and so cannot consult either the original submissions or the translated report for the hearing but must work only from the French version, he or she may not be aware of any problems or discrepancies.

${ }^{29}$ Note: an opinion is not given in every case before the Court of Justice (since 2004 if a case raises no new questions of law then an advocate general's opinion is not necessary); an 'advocate general's opinion' may exceptionally be given in cases before the General Court 
at least the first version, of that judgment. Officially judgments are drafted, discussed, and deliberated on in French; however, it has occasionally been the case that certain General Court competition law cases, in which the language of the case was English, were dealt with entirely in that language. ${ }^{30}$ Unofficially, a number of référendaires interviewed during the course of fieldwork research for the present paper reported drafting 'half in [their own mother tongue] and half in French', many working from glossaries that they had constructed themselves on the basis of 'the settled case law of the Court':

I usually know what I want to say in my own language and then I look at my glossary to find something similar that the Court has said before and use that to help me draft; as a starting point ... I scan my glossary of French terms and phrases frequently used by the Court and find something that covers the gist of what I want to say; I will usually have a basic idea in my head of the direction I want to go in and what I want to say and then I use the set phrases that I have collated in my glossary to start me off and shape what I write.

(Rules of Procedure of the General Court Arts 17-19). However, in such an event, the opinion will be drafted by a judge of the General Court who has been designated 'advocate general' in a specific case (Rules of Procedure of the General Court Art.2). ${ }^{30}$ This has occurred only a handful of times, and is officially 'frowned upon' by the Court of Justice, in particular when such cases come before the Court of Justice on appeal and there are no French documents available from which that Court can work. See McAuliffe, 'Law in Translation' (cited in n.28) for commentary on the use of English at the General Court since the May 2004 enlargement. 


\section{Difficulties of and constraints in drafting: producing a linguistic}

\section{precedent?}

None of the référendaires interviewed for the purposes of the present paper admitted having any difficulty drafting documents in a language that is not their mother tongue (where relevant). Indeed the only référendaires who claimed to have such difficulties were the francophone référendaires who 'simply can't bear' to draft in the 'formulaic, synthetic French used at the Court'!

The mechanical French that is used at the Court is so far removed from 'proper' or 'real' French that it is almost like another language entirely;

The French used at the Court is not 'real' French but a type of 'Court French'. Some commented that having to work in French (where it is not their mother tongue) 'slowed them down', but that, as a result of the rigid formulaic style in which they are 'required' to draft judgments:

working in 'Court French' is actually easier than drafting in your own language - provided that you don't actually want to write anything of your own" [interviewee's emphasis];

Judgments are time-consuming but most are easy to draft because it has all already been said by the Court—maybe once in five or six years a case will come along that might have one single paragraph saying something completely new or different; you never get to produce anything original ... you just write according to the template provided ... in fact I felt little more than a report-writing machine! When questioned about the concept of precedent in EU law, every référendaire interviewed acknowledged that, strictly speaking, there is no rule of precedent within the EU court system and in theory the ECJ and the General Court are not bound by their own previous decisions. 
In spite of that, however, it is clear that those référendaires feel constrained by the language used by 'the Court' and that the judgments they draft reflect their perceptions of such constraint:

We must draft using the language that has been used by the Court for over 50 years;

We are under pressure to cite 'word-for-word' when taking material from source documents ... in particular from past judgments;

We work from templates, and the translators work from templates ... so we cut and paste from previous judgments and the process works for everyone.

There are two main reasons for these perceived constraints: first, some argue that since the Court is building up a European case law and rule of law, it is necessary to use the same terminology constantly throughout that case law:

what you are dealing with is the rule of law in a legal system that is still developing, therefore it is important to use the same terminology and phrases all of the time, in particular because that legal system is expressed in many different languages.

In addition, it is often necessary, in judgments, orders, reports, etc., to refer to provisions of relevant EU legislation. When making such references, référendaires are obliged to use the same specific wording used in the provision in question. ${ }^{31}$

Secondly, as one référendaire put it: 'the pressure of computers is significant'. With the advent and increasing use of the $\mathrm{GTI}^{32}$ at the Court it has become important to cite entire phrases instead of merely referring to them or even

\footnotetext{
${ }^{31}$ McAuliffe, 'Law in Translation' (cited in n.28).

${ }^{32}$ The GTI is a computer programme developed by the Court of Justice to aid and speed up the translation process at that Court.
} 
paraphrasing. Then that phrase will be translated sentence-for-sentence since there is the danger that the text 'pulled up' by the GTI might not fit into the context of the case in hand unless every single word is exactly the same. There is a huge pressure for one single word to be translatable into another single word, which of course is rarely the case;

We are obliged to use the same language over and over- to 'copy-paste' from previous decisions, reports or orders so that the computer programme will pick it up for easy and quick translation. That way translation is also safer as it will not be wrong - it has already been translated and that is now the way that [the relevant concept] is in the case law. It's like a precedent [interviewee's emphasis].

On top of such perceptions of constraint as regards the language that they feel they 'should' use, référendaires are, for the most part, working in a language that is not their mother tongue. This has been the case since the early days of the ECJ. For that reason alone there is, and always has been, a tendency to use the same expressions over and over again: because we are writing in a foreign language there is a tendency to do a lot of 'cutting and pasting' and so the style [in which the Court's judgments, orders, etc. are written] reproduces itself; Working in a language that isn't your own makes you slower but it is not especially difficult because the Court has its own style that you just rigidly follow;

My French is very good, but when I am drafting judgments I will copypaste- because I can't say it better than that way that I have read it in the settled case law. 
Thus it seems that in spite of the claims of the majority of the référendaires that they find it relatively non-problematic to draft in French, it nonetheless has consequences. The 'Court style' of drafting by which those référendaires feel so constrained is shaped in a large part because of the fact that they are drafting in a language that is not their mother tongue. As one référendaire pointed out:

Drafting in a language that is not your mother tongue makes a big difference to the way that you write. When you write in your mother tongue it flows more naturally, it is an unconscious exercise (language-wise), words and phrases flow from associations made by your brain by drawing on a lifetime's use of the language ... When you are writing in a language that is not your mother tongue you have to boil down the semantics of what you want to say into one thread, into the essential of what you want to say- then you have to put your sentences together and you end up using clumsy and clunky connections.

Three of the référendaires interviewed during the first stage of fieldwork research for the present paper feel that because they are 'generalists' as opposed to specialists in a particular area of European law, being thus restrained as regards drafting judgments is actually very useful as 'there is less risk of getting things wrong':

In your own language you have a huge choice of words and phrases and so there is more risk of making a mistake where you are drafting a judgment concerning an area of EU law that you may not be expert in $^{33}$;

\footnotetext{
${ }^{33}$ However, according to some lawyer-linguists such mistakes are even more likely where the référendaire does not fully understand the implications of the translation of their choice of wording or terminology in French — cf. McAuliffe, 'Law in Translation' (cited in n.28), 168-
} 70. 
Because of the workload we cannot specialise in a particular area of EU law, so maybe it is better that we are tied to templates ... we are less likely to make a mistake this way.

However, the vast majority of those interviewed feel frustrated at the constraints under which they must draft:

it is irritating not to have control over how you can express concepts and frustrating to be tied into the 'Court style' of drafting ... only a small percentage of what we draft actually shows any originality at all. Another aspect of drafting that galls the majority of référendaires interviewed (13) is the 'pompous tone' of the Court's judgments. That tone seems to be based on the tone of judgments of the French Cour de Cassation and most référendaires, and indeed many members of the Court, feel that it is quite unnecessary ${ }^{34}$ :

[the référendaires] only write in that stuffy way because they know that if they don't the lecteurs d'arrêts will return the document to the cabinet having changed its tone entirely.

Référendaires also complain that, on top of that, the lecteurs d'arrêts ${ }^{35}$ read their texts with a view to whether they will be easy or difficult to translate and that they insist on reducing connecting phrases, etc. to a basic and quite simple level so that they will be easy to translate:

\footnotetext{
${ }^{34}$ It must be noted that that 'pompous tone' appears to have gradually crept into the judgments of the Court of Justice. In the 1970s (when, incidentally, the President of the Court was a German, Judge Kutcher) the judgments of that Court were much lighter and 'not so stuffy'.

${ }^{35}$ The lecteurs d'arrêts are francophone lawyers who ensure that the judgments read fluently yet remain sufficiently clear and precise.
} 
they push it so far, however, that [the référendaires] are forced to use childish links and are left with infantile simplicity in a complex text with a pompous tone!

An interesting result of référendaires feeling constrained in their style of drafting and bound by the language previously used by the Court is that a type of linguistic precedent is developing in judgments of the Court of Justice in spite of the fact that no such rule actually exists within the EU court system:

decisions of the Court are treated as 'stare decisis' [sic] even though, on paper, those decisions are not binding on future decisions of the Court ... sometimes it seems that precedent is even more binding at the Court than it is in a common law country! [interviewee's emphasis].

Those référendaires interviewed who commented on that phenomenon claim that the reasons for this development of a de facto rule of precedent in Court of Justice judgments are (a) the relative inexperience of most of the référendaires:

who is going to change the wording or contradict something set out by the Court in a previous judgment?

and (b) since most référendaires are drafting in a language that is not their mother tongue and are not as confident as they would be in their own language they tend to use direct quotes and 'take entire chunks' from previous judgments. As a result:

phrases are chiselled out of the rock face of the European Court Reports and considered to be immutable - there is a de facto stare decisis.

\section{Collegiate judgments}

A final factor that restricts how judgments are drafted and thus affects the development of the linguistic style of the Court's case law is the collegiate nature of those judgments. Those judgments are, by their very nature, often compromise documents. However, because the 
deliberations of the Court of Justice are secret and no dissenting opinions are published, it is impossible for anyone other than the judges involved in those deliberations to know where such compromises lie in the text. As many of the référendaires interviewed commented: you don't always know which have been the 'contentious' points in the deliberation ... or how important a specific wording of a particular phrase may be ... therefore it is safer just to stick with phrases that may sound awkward or badly-worded instead of changing them to sound better; there may be part of a judgment that took a long time for the judges to reach a compromise [on]. My judge may be able to tell me which parts are the most important without breaching the secret of the deliberations, but how can I really know? So when a part of a judgment is re-drafted in the secret deliberations I should leave the wording exactly as it is - even if it doesn't make full sense to me, it may be a sign of a compromise between the judges; if the judges have made a compromise in a previous judgment- - how would I know? If something seems vague I can't change the wording to make it more clear because maybe the Court wanted it to be vague - the deliberations are a secret so we will never know. But to be safe we should just repeat the same language.

It seems, therefore, that there are a number of difficulties involved in the creation or drafting of the case law of the Court of Justice of the European Union. On top of having to draft that case law in a language that, in most cases, is not their mother tongue, the référendaires (and indeed the judges) are constrained as regards the language used and the by the fact that the judgments of the Court are collegiate in nature. Such constraints necessarily shape the linguistic development of that case law and thus the development of EU law.

\section{Conclusion}


It is clear that the judges and their référendaires at the Court of Justice seem constrained in how they can draft judgments and other documents. The question thus arises whether language is therefore a constraint on the development of EU law-i.e. does the formulaic style that constrains the référendaires in what they can write actually constrain the development of the case law? The members of the Court interviewed during the fieldwork research for the present paper were of the opinion that, to a certain extent, that is indeed the case:

It is surprising how much the French language influences how the judges deliberate and draft judgments — the fact that French is used as the language of the deliberations and is the language in which the very formulaic judgments are drafted forces [the Court] to speak or rule in a certain way; It is often difficult to say exactly what you want to say in a judgment ... often the Court will want to say $\mathrm{X}$ but in the very rigid French of the Court that is used in the judgments you have to get around to $\mathrm{X}$ by saying that it is not $\mathrm{Y}$ ! ... such use of language necessarily has implications for the way in which the case law develops.

Such constraint is perhaps most immediately obvious in the development of a linguistic precedent in the judgments of the Court. However, the vast majority of literature on the ECJ and on precedent in EU law in particular ignores the linguistic aspect of the development of a rule of law. Legal literature is generally concerned with analysing the legal logic behind the Court's rulings and discussing how that Court can affect policy changes in the EU, insofar as practice may have to change to comply with a particular ruling. Political science literature is interested in 'judicial politics', the policy dynamics that can be inferred from the Court's decisions and in examining the political context and consequences of those decisions. However, each of these bodies of literature remains predominantly focused on the decisions 
of the Court and on judicial reasoning and/or investigating the reasons or motivation behind those decisions. Much has been written on why the Court makes certain decisions and the effects of those decisions, particularly with regard to precedent in the EU; but there has been very little research into how its case law is produced and the role of language in the production of that case law. Even those academics interested in the actors at the Court are primarily interested in argumentation frameworks and organisation theory (courts as organisations) $)^{36}$ and ignore the multilingual aspects of that institution.

This consideration of the linguistic aspect of the development of a de facto precedent at the level of the Court of Justice necessarily leads to consideration of how the synthetic construction of the Court's case law may affect the application of that law by national courts that may not be aware of the body of EU law as a synthetic construction and will be looking for clues as to its application in a national legal language. ${ }^{37}$ This paper thus highlights a need for further research to contribute to the debate mentioned in the introduction, which aims to clarify the way in which 'precedent' may be developing in the case law of the Court of Justice and the effect that may have on the relationship between the ECJ and national courts in the context of the preliminary ruling procedure.

\footnotetext{
${ }^{36}$ Stone Sweet, The Judicial Construction of Europe (cited in n.5).

${ }^{37}$ McAuliffe, 'Hybrid Texts and Uniform Law?' (cited in n.25).
} 